\title{
Reforming legislation in prevention of neglect and juvenile delinquency
}

\author{
Elena Nikolayevna Ryabova ${ }^{*}$, Leonid Ivanovich Savinov², Dmitrii Vladimirovich \\ Bondarenko $^{1}$, and Tatyana Vladimirovna Cherkasova $^{2}$ \\ ${ }^{1}$ Federal Center for Educational Legislation, R\&D department, Moscow, Russia \\ ${ }^{2}$ National Research Ogarev Mordovia State University, Department of Social Work, Saransk, Russia
}

\begin{abstract}
The article represents the results of the analysis of modern legal regulation of the system for prevention of neglect and juvenile delinquency in the Russian Federation and activity of commissions for juvenile affairs and juvenile rights protection as the main authority of that system. Relevance and immediacy of changes and reforming of legislation in the prevention of neglect and juvenile delinquency and areas of such activity are associated with the needs of the modern informational society. The authors analyze regulatory legal acts governing the activity of commissions for juvenile affairs and juvenile rights protection, proposals of executive authorities of constituents of the Russian Federation in the practicability of developing a concept of federal law on prevention of neglect and juvenile delinquency and rights' protection and they characterize primary trends in the activity of this authority in order to define further perspectives of activity within the system of prevention of neglect and juvenile delinquency in Russia. Methodological support of the research are such methods of scientific cognition as analysis and synthesis, comparative-legal, formally legal, analysis of documents, legal modeling, survey, which allowed for a comprehensive approach to the research of this problem. The result of the research was reasoned conclusions on the practicability of reforming authorities and legal relations in the system of prevention of neglect and juvenile delinquency. Models are given for the modernization of commissions for juvenile affairs and juvenile rights protection. The results ensure conceptual basis and trends in the development of proposals for improvement of legal regulatory regulation of social relations in the prevention of asocial behavior and juvenile delinquency.
\end{abstract}

Keywords: commission, concept, modernization models, system of prevention

\section{Introduction}

Today we need to reframe the state policy and conceptual justification of new principles of activity in the prevention of neglect and juvenile delinquency.

Some scientists believe that the activity of the commissions for juvenile affairs and juvenile rights protection (CJAJRP) deserve special attention. Malovichko and Chugunova

\footnotetext{
* Corresponding author: yula1@bk.ru
} 
[1] considered a new area in the activity of CJAJRPs - participation in mediation programs developed for students of educational facilities and their parents. A right protection function of commissions as the primary and most important area of activity in juvenile rights protection is charactered by Kiryushina, Morozaova, Kochneva [2] in their publications. Lebedeva [3], Mozgareva-Marchenko, Rusanova [4] characterize CJAJRPs as an authority that successfully implements juvenile technologies.

Despite specific successes that were achieved in the current system of prevention of neglect and juvenile delinquency, there are problems in the activity of authorities in this system [5, 6]. Scientists critically analyze modern research approaches used by criminologists in researching juvenile delinquency [7] and the organizational structure of the system of neglect and juvenile delinquency prevention.

It is especially relevant to study the legal regulation of CJAJRP activity. A number of modern researchers, practicing lawyers, political and public figures propose either release CJAJRPs from administrative-jurisdiction activity or discontinue the system of CJAJRPs [10-13]. Banshikova believes that it is too early to liquidate CJAJRPs, but it is necessary to release them from administrative-jurisdiction activity, and she underlines that when parents or proxy parents are held administratively liable for failure to fulfill their obligations, there is state intervention into personal non-property family relations and the constitutional property right for children upbringing by parents is violated (Part 2, Article 38 of the Constitution of the Russian Federation; Clause 2, Article 54, Clause 1, Article 61, Clause 1, Article 63 of the Russian Federation Family Code) [10, 11].

As Ilgova fairly notes, today we can observe a direct interrelation between ensuring a unified state approach to solving the issue of protection of juvenile rights and legal interests and ensuring a unified state approach to defining the legal status of commissions [14].

In order to form a domestic system of juvenile delinquency prevention, a successful foreign experience can be used. A number of European countries use a psychodynamic approach that suggests special social-rehabilitation facilities of open and closed type for juveniles - therapeutic communities. For example, Childhood First is a charity organization providing care services in residential care facilities, special education and family support to juveniles aged 12-18. They use a method of comprehensive systemic therapy intended for trauma curing $[15,16]$.

There is a family innervation project in the UK that provides families from a high-risk group with intensive support to undertake positive changes in their life. A number of various authorities provide support to families in making changes until they become capable of efficient functioning and can keep the family integrity. A central authority acts as a mediator for all other services working with families: undertakes regular meetings, provides current support, plans program completion and provides support after the intervention is completed $[17,18]$.

The research was intended to analyze the existing regulatory framework in the prevention of neglect and juvenile delinquency and to develop a new conceptual approach to reforming a legal basis of state policy in this area. A suggestion was made that a number of regulations governing these relations is very big nowadays and it is misaligned and fails to meet the needs of the modern informational society.

\section{Methods}

The article presents the results of the research undertaken in 2020 as a part of the program of the Ministry of Education of the Russian Federation called Development of the Doctrine and Conceptual Basis of Legislation in Prevention of Neglect and Juvenile delinquency.

The research used the following methods: document analysis, comparative method, legal modeling, survey, which allowed for a comprehensive study of the problem. 
Legal documents were analyzed for 85 primary regulations in the sphere of family and childhood concerning prevention of neglect and juvenile delinquency.

The survey included representatives of 86 regions.

\section{Results}

The following results were obtained during the survey.

A number of disadvantages was identified: multiple regulations governing similar relations or duplicating each other; underdeveloped legal definitions - foundational terms used in prevention legislation; duplication of powers of subjects of the prevention system; no legal status of CJAJRP and fuzzy powers of CJAJRP.

Law No. 120-FZ contains no clear regulation of using social rehabilitation centers for teenagers by youth authorities as well as using centers of social-psychological support for youth, centers of career guidance and employment of youth, youth clubs and other facilities whose founders are authorities engaged in management in education, social protection and health care. Therefore, Clause 2, Article 1 of Law No. 120-FZ frequently cannot be implemented and is declarative.

The authorities forming the prevention system have no institutions of culture, leisure, sport and tourism, organizations of additional education for children, leisure and health care of children, socially-oriented non-commercial organizations, psychological, medical, pedagogical commissions, and youth authorities.

Uncertainty of provisions concerning institutional control is identified including that exercised by state federal authorities, over the activity of neglect and juvenile delinquency prevention authorities in accordance with the procedure defined by respective regulations.

The survey of representatives of executive authorities of Russian Federation constituents in terms of practicability of developing a concept of the federal law on neglect and juvenile delinquency prevention and protection of juvenile rights have shown as follows:

- representatives of $38 \mathrm{RF}$ constituents (44.7\%) believe that legislation in this sphere must be improved by making changes to a number of existing regulations;

- representatives of $38 \mathrm{RF}$ constituents (23.5\%) made no proposals for legislation improvement;

- representatives of $21 \mathrm{RF}$ constituents $(24.7 \%)$ provided proposals to develop a concept of federal law by indicating areas requiring accounting: measures to replace a penal character of criminal policy towards juveniles with restorative justice, using mediation as a mechanism to settle conflicts;

- representatives of $27 \mathrm{RF}$ constituents $(31.7 \%)$ find it reasonable to develop a federal law concept.

In this manner, the analysis of proposals in this area shows that most RF constituents find the development of a federal law concept unreasonable and propose paying attention to the improvement of applicable laws in the area of prevention.

\section{Discussion}

The research and study of the experience of similar neglect and juvenile delinquency prevention systems abroad give a model for the modernization of CJAJRPs and of the mechanism for regulation of relations in this area. We propose three options for CJAJRP modernization.

The first option suggests a fundamental modernization of the system with the liquidation of CJAJRP and the establishment of the Federal Service for Family and Children Support 
whose functions will include prevention of neglect and juvenile delinquency and consideration of cases for offenses committed by juveniles.

The second option suggests keeping the suggestions and their functions to coordinate the activity of the neglect and juvenile delinquency prevention system, while consideration of offense cases is transferred to courts, which significantly liberates CJAJRP resources and allows for increased quality of work with juveniles.

The third option suggests maximum succession and minimal structural changes of CJAJRP: kept as an authority coordinating the activity of the neglect and juvenile delinquency prevention system, considers cases of the offense committed by juveniles, but uses a restorative approach in working with juveniles.

The entire mechanism of legal regulation of considered relations must be changed in its contents and must be based on four primary aspects:

1. Creating a three-level system of preventative and social rehabilitation work with juveniles and their families that includes three stages: general prevention work, individual prevention work and special prevention.

2. Creating a unified CJAJRP structure and defining its organizational and legal status.

3. Introducing a unified system for prevention accounting and definition of the concept, types, and authorities of such accounting.

4. Development of criteria and indicators that can objectively reflect the status of prevention activity and results achieved in each specific region. As the results of the research show, no universal criteria of efficiency prevent from an objective evaluation of CJAJRPs in various areas [19].

In this manner, implementation of the proposed trends in reforming will promote more efficient and comprehensive prevention work with juvenile delinquents.

\section{Conclusion}

The results help in the evaluation of the existing legal model of prevention work, the definition of improvements in the legal regulation of relations in this area and proceed to the development of the project of Federal Law On Modifying Individual Regulations for Improvement of the System of Authorities for Prevention of Asocial Behavior and Juvenile Delinquency and Juvenile Rights Protection.

It should be noted that the practice of patching in legislation does not justify itself and constant modifications can, even more, destabilize law-enforcement and legal practice, while the mechanism of legal regulation of the considered legal relations, in general, will not meet the requirements of consistency and objectivity. Developing an individual and comprehensive draft seems a necessary and up-to-date issue of the nearest future.

\section{References}

1. I.S. Malovichko, I.V. Chugunova, Restorative Justice Herald, 13, 23-31 (2016)

2. N.Yu. Kiryushina, L.B. Morozova, E.M. Kochneva, Bus. Ed. Law. Vestnik Volgograd Inst. Bus. 3(36), 196-201 (2016)

3. T.S. Lebedeva, Vestnik KSU 6, 212-215 (2016)

4. L.A. Mozgareva-Marchenko, S.Yu Rusanova, Rol komissii po delam nesovershennoletnikh $i$ zashchite ikh prav munitsipalnykh obrazovanii v obespechenii yuvenalnogo pravoporyadka [Role of the Commission for Juvenile Affairs and Juvenile Rights Protection in Ensuring Juvenile Law Order], in Proc. All-Rus. Sc. Conf.

Human Rights and Freedoms in Development of Modern State, December 9, Krasnodar, 218-222 (2016) 
5. N.V. Dronova, Mon. Law Enf. 1(34), 21-26 (2020) https://doi.org/10.21681/22260692-2020-1

6. E.V. Evstifeyeva, N.V. Dorodonova, Vestnik Saratov St. Leg. Ac. 6(125), 58-63 (2018)

7. E.V. Demidova-Petrova, Mon. Law Enf. 1(22), 7-17 (2017) https://doi.org/10.21681/2226-0692-2017-1-7-17

8. E.V. Demidova-Petrova, Mon. Law Enf. 2(23), 36-45 (2017) https://doi.org/10.21681/2226-0692-2017-2-36-45

9. R.E. Petrova, Blizhaishee okruzhenie pravonarushitelya: problemy pravovogo regulirovaniya [Nearest Surroundings of Delinquents: Issues of Legal Regulation], in Proc. IV All-Rus. Sc. Practical Conf., 139-143 (2019)

10. S.L. Banshikova, Administrativnaya otvetstvennost' za neispolnenie roditelyami ili inymi zakonnymi predstavitelyami nesovershennoletnikh obyazannostei po ikh soderzhaniyu i vospitaniyu [Administrative Liability for Failure to Fulfill Obligations by Parents or Other Representatives of Juveniles in Law in Care and Upbringing], PhD thesis (Omsk, 2017)

11. S.L. Banshikova, Vestnik Sib. Inst. Bus. and Inf. Tech. 3(27) (2018)

12. E. Mizulina, Komissii po delam nesovershennoletnikh mogut byt likvidirovany [Juvenile Affairs Commissions Can Be Liquidated]. Accessed on: March 17, 2021. [Online]. Available: http://kvnews.ru/newsfeed/elenamizulinakomissiipodel amnesovershennoletnihmogutby tlikvidirovany

13. Ukaz Prezidenta Rossiiskoi Federatsii ot 1 iyunya 2012 g. № 761 O Natsional'noi strategii deistvii v interesakh detei na 2012-2017 gody [Presidential Decree, June 1, 2012 No. 761 On National Strategy of Actions in Favor of Children for 2012-2017. Accessed on: March 17, 2021. [Online]. Available: www.pravo.gov.ru

14. E.V. Ilgova, Iss. Juv. Just. 1(39), 29-32 (2012)

15. K. Winter, L. Nison, D. Sweet, E. Smith, S. Millen, P. Connoly, British J. Soc. Work bcaa125, (2020). https://doi.org/10.1093/bjsw/bcaa125

16. European Network of Crime Prevention. Overview of Know-How in Criminality Prevention Among Juveniles in the European Union. Accessed on: March 17, 2021. [Online]. Available: http://www.heuni.fi/en/index/publications/heunireports/europeansourcebook. html

17. G. Fergusson, British J. Welfare Work 47(4), 1007-1023 (2017). https://doi.org/10.1093/bjsw/bcw065

18. UK Department for Education. Family Intervention Projects: An Evaluation of their Design, Set-up and Early Outcomes (2008). Accessed on: March 17, 2021. [Online]. Available: https://www.crimeandjustice.org.uk/sites/crimeandjustice.org.uk/files/family\%20interv ention

19. V.F. Borisova, E.V. Ilgova, I.O. Kuznetsova, Otsenka effektivnosti deyatelnosti sistemy profilaktiki beznadzornosti i pravonarushenii nesovershennoletnikh [Evaluating Activity of the System of Neglect and Juvenile Delinquency Prevention] (Saratov, 2015) 